\title{
THE IMPACT ON IMPLEMENTATION OF PROMOTER PROGRAM POLICY OF THE INDONESIAN NATIONAL POLICE (POLRI) AND CONTROL TOWARD LAW ENFORCEMENT AT THE METROPOLITAN SUBREGIONAL POLICE OF SOUTH JAKARTA
}

\author{
Hari Prayogo Wicaksono \\ Postgraduate Program Student, Master of Government Science Study Program \\ Satyagama University Jakarta, Indonesia \\ Dr. Rahimullah, SH, M.Si \\ Chairman of the Supervising Team, Master of Government Science Study Program \\ Satyagama University Jakarta, Indonesia \\ Dr. Ir. Sriyono Joko Sutopo, MS \\ Members of Supervising Team, Master of Government Science Study Program \\ Satyagama University Jakarta, Indonesia \\ DOI: $10.31364 / S C I R J / v 8.15 .2020 . P 0520771$ \\ http://dx.doi.org/10.31364/SCIRJ/v8.i5.2020.P0520771
}

\begin{abstract}
This study has a background of the existence of law enforcement cases at Metropolitan Subregional Police of South Jakarta. Such law enforcement cases are caused by less effective of the implementation of promoter program policy of the Indonesian National Police (Polri) and control. This study has purpose to know the impact of implementation on such promoter program policy of the Indonesian National Police (Polri) and control toward law enforcement at Metropolitan Subregional Police of South Jakarta, either partially or collectively. It uses proportionate stratified random sampling with totally 80 respondents. This study has a quantitave method with regression analysis. The techniques for data collection use documentation, questionnaires and desktop study.

The result of this study proves that: First, there are positive and significant impacts on the implementation of policy toward law enforcement of $77,2 \%$. Second, there are positive and significant impacts on control toward law enforcement of $69,2 \%$. Third, there are positive and significant impacts on the implementation of policy and control collectively toward law enforcement of $77,3 \%$.
\end{abstract}

Index Term : Implementation of policy, control, law enforcement.

\section{INTRODUCTION}

Domestic security is the main conditions to support the realization of civil society which are fair, wealthy and civilized based on Pancasila and the 1945 State Constitution of the Republic of Indonesia.
One of the mandates of Constitution as the first primary law sources for State Police of the Republic of Indonesia is a mandate in the Preamble of the 1945 State Constitution of the Republic of Indonesat in paragraph four. In addition, the duties and authorities of State Police of the Republic of Indonesia are contained in Article 30 paragraph (4) of the 1945 State Constitution of the Republic of Indonesia regulating that "State Police of the Republic of Indonesia as state instrument that keeps public safety and order and has duties to protect, nurture and serve the people as well as enforce the law".

Based on Article di atas, it is clear that State Police of the Republic of Indonesia is a part of defense and security of Indonesia as a guardian of defense and security of the Indonesian people from Sabang to Merauke in cooperation with the Indonesian Army (TNI).

Based on the Constitution mandate in the maintenance of such domestic security, it is issued Law Number 2 of 2002 on State Police of the Republic of Indonesia or hereinafter referred to as Law Number 2 of 2002 on the Indonesian National Police (Polri).

State Police of the Republic of Indonesia, hereinafter referred to as the Indonesian National Police (Polri), is one of the law enforcement agencies in Indonesia as regulated in Article 2 Law Number 2 of 2002 on the Indonesian National Police (Polri) stating that the Police is one of the state government functions in the field of maintaining public security and order, law enforcement, protection, nurturance and services to the community. According to Article 13 of Law Number 2 of 2002 on the Indonesian National Police 
(Polri), the Police have main duties to maintain public security and order, enforce the law and provide protection, nurturance and services to the community.

The visions of the Indonesian National Police (Polri) are the realization of optimum services of public security and order, the enforcement of law, steady domestic security and good and proactive relations of the police synergy (the Indonesian National Police (Polri).go.id).

The missions of the Indonesian National Police (Polri) are as follows:

1. Perform early detection and warning through the activity/operation of investigation, counter-intelligence and supportive operations;

2. Provide protection, nurturance and services easily, responsively and non-discriminatively;

3. Keep the traffic security, order and ease to guaranty the safety and ease of the flows of people and goods;

4. Assure the success of handling domestic security interferences;

5. Develop the community policing based on people's compliance to law;

6. Uphold the law professionally, objectively, proportionally, transparently and accountably to assure legal certainty and sense of justice;

7. Manage professionally, transparently, accountably and modernly all resources of the Indonesian National Police (Polri) in order to support the operational duties of the Indonesian National Police (Polri);

8. Build a policing synergy system inter-department and international institution and components of people for partnership bulding/networking.

Other than the vision and missions of the Indonesian National Police (Polri) mentioned above precisely on July $13^{\text {th }}$ 2016, when the General Police Tito Karnavian was inaugurated to become the Chief of the National Police of the Republic of Indonesia (The Chief of the Indonesian National Police (Polri)), propagandizes a "Promoter" Program which is the abbreviation of "Proffesional, Modern and Trusthworthy" with these following explanations:

- Proffesional

Improve the competence of human resources of the Indonesian National Police (Polri) to be more qualified through the capacity of education and training and perform the policing patterns based on standard procedures that have been understood, performed and measured its success.

\section{- Modern}

Perform modernization in public services which is supported by technology so that it is easier and promptly accessed by the people, including the fulfillment of the need of more modern special material tools (Almatsus) and security equipment (Alpakam).

- Trustworthy

Perform an internal reform toward the Indonesian National Police (Polri) that is clean and free from Corruption, Collusion and Nepotism (KKN) for the realization of objective, transparent, accountable and equitable law enforcement.

The "Promoter" program of the Chief of the Indonesian National Police (Polri) contains 10 programs and 1 Quick
Wins of the priorities that have been determined by the Chief of the Indonesian National Police (Polri) as follows:

1. Stabilization on internal reform of the Indonesian National Police (Polri);

2. Improvement of public services which are easier for Technology and Information-based community;

3. Handling of radical group of pro-violence and intolerance more optimally;

4. Improvement of the professionalism of the Indonesian National Police (Polri) toward excellence;

5. Improvement of the welfare of members of the Indonesian National Police (Polri);

6. Institutonal governance, the fulfillment of budget proportionality and minimum need of facilities and infrastructure;

7. Build awareness and people participation toward public security and order;

8. Strenghening of the maintenance of security and order;

9. More professional and equitable law enforcement;

10. Strengthening of control;

11. Quick Wins of the Indonesian National Police (Polri)

The core Promoter program of the Indonesian National Police (Polri) initiated by the Chief of the Indonesian National Police (Polri) is the willingness to improve public services and obtain public trust toward the Indonesian National Police (Polri) including the law enforcement performed by the institution and officers in scope of State Police of the Republic of Indonesia.

This Promoter Program of the Chief of the Indonesian National Police (Polri) should be performed by all organizations of the Indonesian National Police that include the center level or called the headquarters of the Indonesian National Police (Polri) (Mabes Polri), at provincial level which is called Regional Police (Polda), at Regency or City level which is called Resort Subregional Police (Polres) and at Sectoral level or Sub-District which is called Sector Police (Polsek).

One of the institutions in scope of the Indonesian National Police (Polri) administering the main duties of the Indonesian National Police (Polri) in enforcing law is the Metropolitan Resort Police of South Jakarta or Metropolitan Subregional Police of South Jakarta as the executive of duties of the Indonesian National Police in an administrative city area of South Jakarta.

In conducting its main duties, the Metropolitan Subregional Police of South Jakarta is supported by the existence of working units under it. Some working units under the institution of Resort Subregional Police of South Jakarta are Criminal Investigation Unit, Drugs Investigation Unit, Traffic Unit, Patrol Unit (Sabhara), Prisoners and Evidence Gathering (Tahti) Unit, Inteligence and Security (Intelkam) Unit and Public Affairs and Press (Humas).

Nevertheless, the administration of law enforcement as one of the duties of Metropolitan Subregional Police of South Jakarta still needs to be improved. Law enforcement at Metropolitan Subregional Police of South Jakarta includes criminal law enforcement (including drugs/narcotics).

Based on the criminal rate in South Jakarta along the year of 2018, it decreases 28 percents compared to its previous year of 2277 cases from previously 3125 cases.Drugs abuse is still the highest case with 571 cases followed by a theft with 
aggravation as sum of 204 cases, severe persecution of 99 cases, motor vehicle's theft of 94 cases and other number of cases. Nevertheless, there are still many complaints made by the people, either directly or indirectly toward the implementation of law enforcement, either in preliminary investigation or full investigation.

Law enforcement is important because as a Nation of Laws, Indonesia should perform such law enforcement. The State should protect its citizens from various kinds of injustice, uncomfort and other legal violations. In addition, the State has power to force all of its citizens to perform all provisions.

Such law enforcement cases are mostly alleged caused by less effective of the implementation of the policy of Promoter program of the Indonesian National Police (Polri) and its control so that it impacts on its law enforcement.

Such less effective of the implementation of the policy of Promoter program of the Indonesian National Police (Polri) is caused, among others, due to still lower understanding of some members of the Indonesian National Police (Polri) on the policy of Promoter program of the Indonesian National Police (Polri) determined as one of the priorities of the Chief of the Indonesian National Police (Polri). Various understanding of members of the Indonesian National Police (Polri) on the policy of Promoter program of the Indonesian National Police (Polri) can be measured from the ease of community in obtaining services, the readiness of members of the Indonesian National Police (Polri) to give explanation to the community and transparent information on cases to the community as well as the behavior of the Police members toward community in the practice of implementation of law enforcement.

a. The problems of less effective control are among others, lack of discipline of some Police members in working. There are still certain Police members misbehave in the implementation of law enforcement at field so that it impacts the good image of the Indonesian National Police (Polri) in people's view. Law enforcement needs to be more forceful for such misbehaved Police members and the criminal actors. Therefor, to reduce or minimize such violation, it needs more effective control as in the internal control in scope of Metropolitan Subregional Police of South Jakarta and external control as well. But then, such effective control does not mean anything if it is not supported by effective implementation of policy on Promoter program of the Indonesian National Police (Polri)

\section{LITERATURE REVIEW}

Based on the background above, the identifications of problems in this study are :

1. The understanding of some members of the Indonesian National Police (Polri) on the implementation of policy on Promoter program of the Indonesian National Police (Polri) is still low;

2. Human resources have different educational background and field experience so that it impacts the implementation;

3. There are still certain members of Police who misbehave so that it is necessary to improve in order to be more effective in its control;
4. There are still certain members of Police who have "personal interest" for different purpose in the implementation of law enforcement so that it needs to improve in order to be more effective in its control;

5. There are still many complaints from community both directly and indirectly toward law enforcement;

6. Limited number of personnel and facilities in the implementation of law enforcement in the office and at field.

\section{Restriction of Problems}

In order to have more focused and comprehensive study, this study restricts only on variables of policy implementation, control and law enforcement. It is due to the implementation of policy on Promoter program of the Indonesian National Police (Polri) and its control is a factor assumed determinant impacting law enforcement at Metropolitan Subregional Police of South Jakarta. The locus in this study is Metropolitan Subregional Police of South Jakarta.

\section{Formulations of Problems}

Formulations of problems in this study are as follows:

1. How significant is the impact of implementation of the policy on Promoter Program of the Indonesian National Police (Polri) toward law enforcement at Metropolitan Subregional Police of South Jakarta?

2. How significant is the impact of control toward law enforcement at Metropolitan Subregional Police of South Jakarta?

3. How significant is the impact of implementation of Promoter program of the Indonesian National Police (Polri) and its control collectively toward law enforcement at Metropolitan Subregional Police of South Jakarta?

\section{Purpose and Objective of Study}

The purpose of this study is to investigate the factors that impact law enforcement, namely the implementation of policy on Promoter Program of the Indonesian National Police (Polri) and its control.

The objective of this study is to analyze:

1. Significant impact of implementation of Promoter Program Policy of the Indonesian National Police (Polri) toward law enforcement at Metropolitan Subregional Police of South Jakarta.

2. Significant impact of control toward law enforcement at Metropolitan Subregional Police of South Jakarta.

3. Significant impact of implementation of Promoter Program Policy of the Indonesian National Police (Polri) and its control collectively toward law enforcement at Metropolitan Subregional Police of South Jakarta.

\section{Framework of Thinking}

In 2016, the policy of "Promoter" program has been issued which is the Indonesian National Police (Polri) of being professional, modern and trustworthy. The policy of Promoter Program of the Indonesian National Police (Polri) has purpose to improve public services and intends to get public trust in the Indonesian National Police (Polri) including herein on law enforcement performed by the institution and officers in scope of State Police of the Republic of Indonesia. 
With regard to the importance of implementation of Promoter program policy of the Indonesian National Police (Polri), it should be understood and

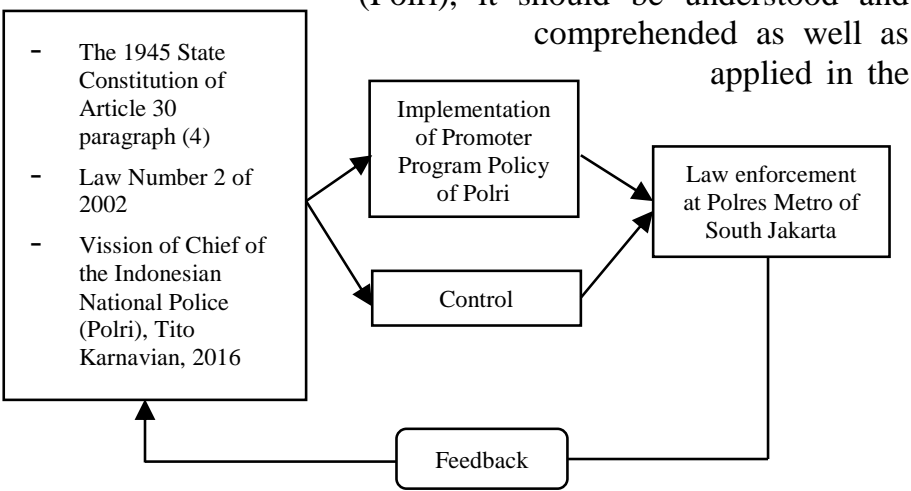

implementation of daily duties and works of the members of the Indonesian National Police (Polri), so that it can influence law enforcement as the duties and functions of the Indonesian National Police (Polri). The implementation of policy is principally a way that a policy can achieve its purpose.

According to Abidin (2006:192), the implementation of policy is the implementation of Government decisions which are general and applicable for all members of community. Implementation is a phase of policy between the establishment of program and consequence of policy for community impacted by it. If a program is not proper or it cannot reduce problems as a target of policy, then such program will possibly fail. Based on this thing, it can be known that the implementation of program policy has important and determinant role in overcoming problems as a target of policy, including Promoter program policy of the Indonesian National Police (Polri).

Whereas the realization of law enforcement is caused, among others, by an effective implementation of policy as in the implementation of Promoter program policy of the Indonesian National Police (Polri). According to Muchsin and Fadillah Putra (2002:39), the relations of law enforcement are law and public policy as seen from its review field of which one of them are implementation, other than formulation and evaluation.

In addition to the implementation of Promoter program policy of the Indonesian National Police (Polri), one of the aspects related to law enforcement in the context of this study is control. Control has important role in realizing equitable law enforcement in accordance with prevailing laws and regulations.

According to Sule and Saefullah (2005:317), control is as process in determining the size of law enforcement and taking action that can support the achievement of the expected result in accordance with law enforcement that has been determined.

Control is one of the very important things to be considered in the management because it really influences law enforcement. Control is really needed toward law enforcement in order not to cause any misuse in its authority. If such control is conducted effectively according to norms, procedures, standards and criterions, such equitable law enforcement shall be realized.

According to Soekanto (2010:35), law enforcement is an activity of harmonizing the relation of values described in steady norms and the act of manner as series of description of final phase values in order to create, maintain and keep peace of social life.

The guaranty of equitable law enforcement shall encourage the creation of justice for the people. Therefore, law enforcement is an important thing that should be achieved by Metropolitan Subregional Police of South Jakarta, because law enforcement is a reflection of the ability of organization (the Indonesian National Police (Polri)) which is characterized by the success of law enforcement by law enforcement officers upon the achievement of justice values in the community.

Based on frameworks of thinking above, such frameworks of thinking can be visually described as follows:

\section{Figure 1.1 \\ Frameworks of Thinking}

\section{Hypothesis}

Based on the above frameworks of thinking, the hypotheses of this study are as follows:

1. It has impact on the implementation of Promoter program policy of the Indonesian National Police (Polri) toward law enforcement at Metropolitan Subregional Police of South Jakarta where the more effective implementation of Promoter program policy of the Indonesian National Police (Polri), the better its law enforcement shall be.

2. It has impact on control toward law enforcement at Metropolitan Subregional Police of South Jakarta, where the more effective control, the better its law enforcement shall be.

It has the impact on implementation of Promoter program policy of the Indonesian National Police (Polri) and control collectively toward law enforcement at Metropolitan Subregional Police of South Jakarta where the more effective implementation of Promoter program policy of the Indonesian National Police (Polri) and its control, the better of its law enforcement shall be.

\section{METHOD OF STUDY}

Method of study used in this study is a quantitative method. According to the type, this study is an explanatory study to test the hypothesis that states a causal relation between two variables or more.

\section{Population and Sample}

According to Arikunto (2013:173), population is the whole subject of study. Population of this study is totally 100 persons. This study uses proportionate stratified random sampling (Sugiyono, 2014:64) where the population has nonhomogenous members/elements. This study has samples of 80 respondents from 100 persons of the population. 


\section{RESEARCH RESULTS AND DISCUSSION}

\section{The Impact on Implementation of Promoter Program Policy of the Indonesian National Police (Polri) toward Law Enforcement}

Based on the analysis result, it is proved that the implementation of Promoter Policy of the Indonesian National Police (Polri) partially has positive and significant impacts on law enforcement at Metropolitan Subregional Police of South Jakarta.

The realization of effective implementation of Promoter Policy of the Indonesian National Police (Polri) in law enforcement is determined by internal factor, external factor as the implementation of Government decisions which are general and applicable for all members of community. It is in line with the restriction made by Abidin (2006:192) that the implementation of policy is the implementation of Government decisions which are general and applicable for all members of community. Thus, law enforcement at Metropolitan Subregional Police of South Jakarta shall be realized if it has an implmentationm of Government decisions which are general and applicable for all effective members of community.

Based on the findings of analysis result, it can be known that the indicators in the implementation of Promoter Policy of the Indonesian National Police (Polri) having important roles on law enforcement are human resources, people participation and operational environment condition.

Human resources have important role in the implementation of policy, especially human resources as the implementer at field that implements the policy. Edward III in Widodo (2011:98) states that the implementation of policy shall not be successful without any support from human resources that have enough quality and quantity. The quality of human resources relates to the skill, dedication, professionalism and competence in its field, meanwhile the quality relates to the number of human resources whether it has been adequate or not to cover all groups of targets. The role of resources in the process of policy implementation is very important. If we look through this, how obvious and consistent of the rules as well as the provision in a policy and the accuracy in expressing the purpose and objective of such policy should be consistently supported by adequate availability of human resources.

The indicator of people participation has important role in the implementation of Promoter policy of the Indonesian National Police (Polri) as a government policy. Public policy shall become meaningless for the people where in the process of formulation and its implementation without involving people participation. In the context of democracy system, such participation has vital role. A democratic State makes possible that people participation occurs fully in the State affairs (Handoyo, 2008:151).

Public policy shall not be effectively implemented if there is no people participation. Verhangen in Mardikanto (2013:167) defines participation as a form of participation or involvement of a person (an individual or a community) in a certain activity. Participation does not mean something that is given by the Government, but it should be deemed as a fundamental right of a citizen in the process of development and as a prerequisite for the establishment of other rights (Sutoro Eko in Abe, 2005:14-15). Whereas the success of the implementation of policy on the Promoter of the Indonesian National Police (Polri) is not merely the responsibility of the Indonesian National Police (Polri), but also the responsibility of the people. Therefore, people participation is required for a form of support toward the policy of Promoter at Metropolitan Subregional Police of South Jakarta that can be realized by performing and complying with regulations that have been determined. The policy of Promoter made by the Chief of the Indonesian National Police (Polri) is not only designated and performed internally at Metropolitan Subregional Police of South Jakarta, but also it is designated and should be implemented as well by all institutions of the Indonesian National Police (Polri) in Indonesia.

Operational environment indicator has important role in the implementation of policy of Promoter. Grindle in Agustino (2008:192) states that the implementation of policy is influenced by two (2) big factors of which one of them is a policy environment factor that includes how big is the power, interests and strategies owned by the actors involved in the implementation of policy, the chracteristitcs of institutions and rezimes in power and the level of compliance and responsiveness of targets. Rondinelli and Cheema in Purwanto and Sulistyastuti (2012: 90) identify one of the factors that influence the performance of policy implementation, namely environmental conditions other than inter-organizational relationship, resources and characteristics of the implementing agencies. Environment, in this case, the operational environment really influences the implementation of policy and determines the success of the implementation of such applied policy. It is because however good the policy, it shall be difficult to be implemented if the existing environmental condition may not suppprt such implementation.

\section{The Impact on Control toward Law Enforcement}

Based on the analysis result, it is proved that partial control has positive and significant impacts toward law enforcement at Metropolitan Subregional Police of South Jakarta.

The realization of effective control in law enforcement is determined by standards of control, implementation and corrective actions as a process in determining the size of law enforcement and action taking. It is in line with the restriction of Sule and Saefullah (2005:317) that control is a process in determining the size of law enforcement and action taking that can support the achievement of the expected result in accordance with law enforcement that has been determined.

Control is very important because it is a benchmark in giving evaluation toward the work/duty of a person or a group in an institution and organization. Control has function to help ensuring whether the activity conducted by members of Polres Metro of South Jakarta is in accordance with the purposes and desired aspirations. In addition, this function can also be used to facilitate how to make improvement and evaluation toward deliverables. The purpose of control is to know and evaluate an actual fact on the object under control whether it is appropriate or not.

Based on the findings of analysis result, it can be known that the indicators in control with important roles toward law enforcement are monitoring, mass media and sanction.

A monitoring indicator has important role in controlling law enforcement. Dunn (2003:6) says that 
monitoring is a procedure of descriptive evaluation intended to identify and/or measure the impact of on-going activities without questioning a causality relation.

Monitoring can be defined as awareness on things that would like to know. This monitoring is also intended that the system of implementation of Promoter Program at Metropolitan Subregional Police of South Jakarta can carry on as desired. Monitoring shall be more useful and meaningful if it is conducted by direct superior so that the violation possibly made shall be detected earlier. Thus, it can be stated that monitoring indicator has important role in controlling law enforcement at Metropolitan Subregional Police of South Jakarta.

Another indicator is mass media as a form of external control which presently sensed effective. Mass media or in this case referred to as journalistic media is the main instrument in the process of mass communication. Mass media is one of the means of meeting human needs on information. Mass media is the result of modern technology product as a means in mass communication.

According to Sumadiria (2005:32), the main function of mass media is to deliver information to the community and each information submitted should be accurate, factual, interesting, accurate, completely-intact, relevant equal and useful. Mass media is not only as information submission means, but also it functions as social control. Mass media has very huge impact in a social life so that it can be utilized as a controlling media on a policy carried on by Government such as the Promoter Policy of the Indonesian National Police (Polri) whether it has been implemented well or not. By having the role of control on this mass media, it can be known how far such level of success of the policy has been implemented or not according to the expected purpose.

The indicator of sanction has important role in controlling law enforcement. Sanction is an act in form of sentence given to a person who breaks the regulations. Sanction derives from Dutch language, namely Sanctie that means a threat of sentence as a forcing means in compliance of the norms, the legislations such as sanction toward a violation of legislation (Simorangkir, 2000:152). Sanction in control is an act or sentence to force a person complying with regulations or provisions. Sanction in the implementation of control is given if there have been found the violations of law or act deemed harmful for the interest of many people and the State. Sanction can be given in form of penal sanction (criminal, civil and administration) or fines in accordance with prevailing laws and regulations.

\section{The Impact on Implementation of Promoter Policy of the Indonesian National Police (Polri) and its Control collectively toward Law Enforcement}

Based on the analysis result, it is proved that the implementation of Promoter Policy of the Indonesian National Police (Polri) and its control collectively has positive and significant impacts on law enforcement di Metropolitan Subregional Police of South Jakarta.

According to Soekanto (2010:35), law enforcement is an activity of harmonizing the relations of values described in steady norms and the act of manner as series of description on the final phase values in order to create, maintain and keep peacefulness of social life. The main purpose of law enforcement is to realize a sense of justice, legal certainty and usefulness in the community. In addition, it should have reflected the aspects of legal certainty and law order. The Indonesian National Police (Polri), in this case, has owned the working guidance of Catur Prasetya, ways of life of Tri Brata, and the Code of Ethics on the Profession of the Indonesian National Police (Polri) as a basis of law enforcement to be implemented.

Based on the findings of analysis result, it can be known that the indicators with important roles in law enforcement are accountability, objective and equitable.

Accountability indicator has important role in law enforcement. Law enforcement is a part of law system. Without law enforcers, material legal norms shall only be useless stacks of papers. Therefore, we need accountable system of law enforcement.

According to Adisasmita (2011:30), accountability is an instrument of accountability for the success and failure of the main duties and functions as well as missions of the organization. Accountability is a realization of obligation of a person or a group in an organizational unit to account for every activity in the management and control of resources and policy implementer mandated to him/her in order to achieve such purpose that has been determined.

Accountable law enforcement can be defined as an effort of implementation of law enforcement accountable to the community, nation and state concerning or related to the existence of legal certainty in a prevailing law system, legal benefits and justice for the community. Accountable law enforcement is a base and evidence that Indonesia is really a Nation of Laws (rechtsstaat). Such law accountability is related with having been complied with other laws and regulations required in the organization and ensured the enforcement of law supremacy.

A transparency indicator has an important role in law enforcement. Transparency is a principle of creating mutual trust between Government and the community by providing information and ensuring an ease in getting accurate and adequate information.

Mardiasmo in Kristianten (2006:45) mentions that a transparency is the openness of Government in giving information related to the activity of management of public resources to the party in need, namely the community.According to Kristianten (2006:31), a transparency shall give positive impact in the governance. Transparency shall increase accountability of policy formulators, including law enforcement so that people's control toward the authority holders of policy making shall work effectively.

Transparency in law enforcement can be meant if law enforcing agency or law enforcer has developed the transparency system of public information on the cases being handled. Transparency in law enforcement is to avoid misperception and multi interpretations that finally may harm such law enforcing agency itself. On the other side, the transparency of the process of law enforcement can also encourage the level of people's satisfaction on the performance of law enforcement officers which in turn, it can increase people's trust. On the contrary, the public also has the right to test such transparency of law enforcement.

Then, an equitable indicator has important role in law enforcement. The essence in law enforcement is justice. In principle, justice is an adjective word that means equitable or 
impartial or non-favoritism. This character is one of the human characters. Justice is a concept that indicates a sense of justice in the treatment (Nurrachman, 2004:13).

Equitable law enforcement has a reason in order to be able to create public justice and order. Indonesia is a Nation of Laws. Laws are the regulations that have purpose to regulate the life and create public order. Laws should be enforced consequently in order to create peacefulness and welfare for all people. The main purpose of law enforcement is to make people feel that they obtain protection on their rights.

Law enforcement is a process of making effort for the enforcing or functioning of legal norms factually as a code of conduct in the life of the people and of the nation. Law enforcement is one of the efforts to achieve or create a code of conduct, safety and peace of the people, either as preventive and eradicative efforts or prosecution after the occurrence of law violation. The main duty of law enforcement is to realize a justice. Law enforcement system with good values can guaranty the social life of the people that are more prosperous, assured and equitable.

\section{CONCLUDING REMARKS}

\section{Conclusion}

1. There are positive and significant impacts on the implementation of the policy of Promoter of the Indonesian National Police (Polri) toward law enforcement at Metropolitan Subregional Police of South Jakarta of $77,2 \%$. But the implementation of the policy of Promoter of the Indonesian National Police (Polri) is in fact still less effective and performed less effectively. It is caused by lack of support from the indicator roles of human resources, people participation and operational environment condition in the implementation of policy so that all of them impact on law enforcement at Metropolitan Subregional Police of South Jakarta.

2. There are positive and significant impacts on control toward law enforcement at Metropolitan Subregional Police of South Jakarta of $69,2 \%$. But the expected control in line with law enforcement is in fact less effective and performed less effectively. It is caused by lack of support from the indicator roles of monitoring, mass media and sanction in control so that all of them impact on law enforcement at Metropolitan Subregional Police of South Jakarta.

3. There are positive and significant impacts on the implementation of the policy of Promoter of the Indonesian National Police (Polri) and its control collectively toward good law enforcement at Metropolitan Subregional Police of South Jakarta of $77,3 \%$. But law enforcement is in fact not yet implemented well. Such law enforcement not yet well-implemented is caused by lack of support from the indicator roles of accountability, objective and equitable where all of them impact on law enforcement at Metropolitan Subregional Police of South Jakarta. In addition, it is also caused by less effective implementation of the policy of Promoter of the Indonesian National Police (Polri) and its control.

\section{Suggestion}

1. That the implementation of promoter's policy of the Indonesian National Police (Polri) as an implementation of Government decision which is general and applicable for all members of communities in order to be more effective in its application and performed concretely so that good law enforcement at Metropolitan Subregional Police of South Jakarta can be realized. Thus, it is recommended that human resources indicators, people participation and operational environmental condition should be paid attention more so that the implementation of such policy of the promoter of the Indonesian National Police (Polri) becomes more effective in the future.

2. That the control as a process in determining the size of law enforcement and taking action that can support the achievement of the expected result has been in accordance with law enforcement already determined in order to be more effective and performed concretely so that such good law enforcement at Metropolitan Subregional Police of South Jakarta can be realized. For this regard, it is recommended that the indicators of monitoring, mass media and sanction should be paid attention more so that the control is expected to become more effective in the future.

3. That the law enforcement as an activity of harmonizing the relation of values described in steady norms and the act of manner as series of describing the values of the final phase should be much better. For this regard, it is recommended that the indicators of accountability, objectivity and equitability should be paid attention more followed by effective implementation of the policy of promoter of the Indonesian National Police (Polri) and its control so that such law enforcement at Metropolitan Subregional Police of South Jakarta can be realized into much better in the future according to the main duties and functions of the Indonesian National Police (Polri).

\section{REFERENCES}

\section{Book:}

[1] Abe, Alexander, 2005, Perencanaan Daerah Partisipatif, Yogyakarta: Pembaharuan.

[2] Abidin, Said Zainal, 2006, Kebijakan Publik, Cetakan Ketiga, Jakarta: Suara Bebas.

[3] Adisasmita, Rahardjo, 2011, Pengelolaan Pendapatan dan Anggaran Daerah, Yogyakarta: Graha Ilmu.

[4] Agustino Leo, 2008, Dasar-Dasar Kebijakan Publik, Bandung: Alfabeta.

[5] Dunn, William N., 2003, Public Policy Analysis: An Introduction, Edisi Kelima, Terjemahan, Yogyakarta: Gadjah Mada University Press.

[6] Handoyo, B. Hestu Cipto, 2008, Prinsip-prinsip Legal Drafting dan Desain Naskah Akademik, Yogyakarta: Universitas Atma Jaya Yogyakarta.

[7] Kristianten, 2006, Transparansi Anggaran Pemerintah, Jakarta: Rineka Cipta.

[8] Mardikanto dkk, 2013, Pemberdayaan Masyarakat dalam Perspektif Kebijakan Publik, Bandung: Alfabeta.

[9] Nurrachman, Nani, 2004, "Keadilan dalam Perspektif Psiko-Sosial" dalam buku Keadilan Sosial: Upaya Mencari Makna Kesejahteraan Bersama di Indonesia, Jakarta: Kompas.

[10] Purwanto, Agus Erwan dan Dyah Ratih Sulistyastuti, 2012, Implementasi Kebijakan Publik, Konsep dan Aplikasinya di Indonesia, Yogyakarta: Gaya Media.

[11] Simorangkir, J.T.C., Erwin, R.T dan Prasetyo, J.T., 2000, Kamus Hukum, Jakarta: Bumi Aksara. 
[12] Soekanto, Soerjono, 2010, Faktor-Faktor yang Mempengaruhi Penegakan Hukum, Jakarta: PT. Raja Grafindo Persada.

[13] Sugiyono, 2014, Metodologi Penelitian Kuantitatif Kualitatif dan $R$ \& D, Bandung: Alfabeta.

[14] Sule dan Saefullah, Erni Tris Kurniawan, 2005, Pengantar Manajemen, Jakarta. Prenada Media.

[15] Sumadiria, As.Haris, 2005, Jurnalistik Indonesia, Menulis Berita dan Feature, Panduan Praktis Jurnalis Profesional, Bandung: PT. Remaja Rosdakarya.
[16] Widodo, Joko, 2011, Analisis Kebijakan Publik: Konsep dan Aplikasi Analisis Proses Kebijakan Publik, Malang: Bayu Media.

\section{Legislations :}

[17] The 1945 State Constitution of the Republic of Indonesia.

[18] Law of the Republic of Indonesia Number 2 of 2002 on State Police of the Republic of Indonesia. 